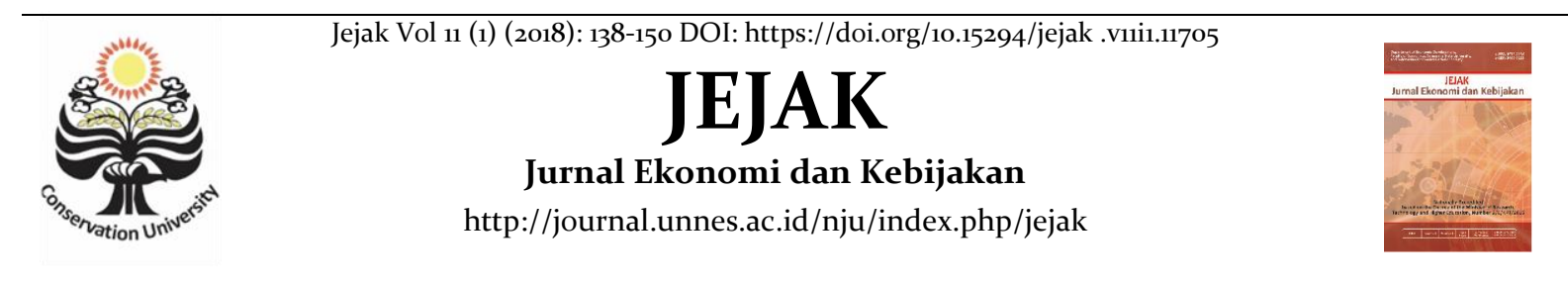

\title{
Strategy to Increase the Competitiveness of SME's Entreprises
}

\author{
Yanah $^{1}$, Haulah Nakhwatunnisa ${ }^{2}$, Tri Amalia Sukarno ${ }^{3}$ \\ ${ }^{123}$ Faculty of Economic, University of 17 Agustus 1945, Cirebon \\ Permalink/DOI: https://doi.org/10.15294/jejak .v11i1.11705
}

Received: October 2017; Accepted: January 2018; Published: March 2018

\begin{abstract}
The purpose of this study is to determine what factors can improve the competitiveness of SMEs and how big those factors affect the improvement of competitiveness of SMEs and what strategies should be done by SMEs in the face of ASEAN economics for the business actors of SMEs in Indonesia in particular in Cirebon district can compete with foreign business actors in terms of products and trained human resources so as not to be a spectator in the State itself in global competition. The method used is a survey research methods and data analysis tool used is path analysis. The population in this study is SMEs that run business activities in Cirebon regency as much as 10.975 SMEs. The sampling technique is simple random sampling, the sample size in this study as many as 100 SMEs. The research instrument used is the questionnaire. The results of the research note that funding variables, entrepreneurship training, business assistance and partnership have an effect on competitiveness in facing ASEAN economics. Among the variables that have the most influence on competitiveness are partnerships, while the variables affecting the ASEAN economy are competitiveness variables.
\end{abstract}

Key words : Perpetrators of SMEs, Competitiveness, ASEAN economics.

How to Cite: Yanah, Y., Nakhwatunnisa, H., \& Sukarno, T. (2018). Strategy to Increase the Competitiveness of SME's Entreprises. JEJAK : Jurnal Ekonomi dan Kebijakan, 11(1), 138-150. doi : https://doi.org/10.15294/jejak. v11i1.11705

\footnotetext{
Corresponding author :

Address: Jl. Perjuangan No. 17 By Pass, Cirebon, West Java

E-mail: yanah@untagcirebon.ac.id 


\section{INTRODUCTION}

ASEAN, which groups 10 countries, namely Indonesia, Thailand, Malaysia, Singapore, Philippines, Brunei Darussalam, Vie tnam, Laos, Myanmar and Cambodia have agreed to speed up the establishment of the ASEAN community by 2015. The establishment of ASEAN Community by 2015 based on three pillars, namely the ASEAN Security Community (ASEAN Security Community), the ASEAN Economic Community (ASEAN Economic Community), and the ASEAN Socio-Cultural Community (ASEAN Socio-Cultural Community). ASEAN Economic Community (ASEAN Economic Community / AEC) in 2015, an ak directed to the formation of a regional economic integration by reducing trade transaction costs, improve trade and business facilities, as well as gkatkan menin the competitiveness of the SMEs sector. Implementation of AEC 2015 will focus on 12 priority sectors, which terdir i of 7 (seven) goods sectors, namely agriculture, equipment, electronic, automotive, fisheries, industrybased rubber, indu stri-based wood, and textiles, and five (5) service sector namely air transportation, health care, tourism, logistics, and information technology ustri ind or eASEAN ( www.depkop.go.id ).

SMEs is one source of stable employment for the community so it needs to be supported by facilitate access to finance. In addition, SMEs can reduce the economic disparities of the Indonesian population, because most MSMEs are in the country side and the managers are the lower middle class, so that with the expected expenditure the percentage of the poor in Indonesia can be reduced as the economic crisis that occurred in 1997-1998 in the Asian region that SMEs is able to sustain the people's economy and contribute in reducing unemployment when many large industries are out of business. If SMEs financing is well distributed, it will equalize the regional income and increase the local currency turnover.

Based on information from the Department of Cooperatives and SMEs Cirebon district there are several centers of leading business types are :

From the data in Table 1 is known that the number of SMEs that have the type of preeminent business amounted to 6,216 while SMEs are not pre-eminent business there are around 4,759 SMEs in ten sub-districts of Cirebon include workshops, photo copy, washing, stalls, convection, salon, shops, pottery, bricks, livestock, refill, tofu, noodles, cookers, printing, transportation, welding, paving brick, husks, cookies, crackers, restaurants, farms, fish, and other assets between 50 million and 50 o million and a turnover of between 300 million to 2.5 billion

Based on the data in the table 1 note that the number of SMEs quite a lot therefore it is necessary to improve the competitiveness of SMEs sector in order to improve the welfare of the community in the face of the ASEAN economy.

There are several studies that have been done on MSME sector such as : Zuraida, Hani, Z; Norlena, Hasnan \& Shahimi, Mohtar (2015), the reserach result is Communication and Innovation is important for MSMEs because it can improve the competitiveness of companies, industries and economies. Innovation in SMEs is to make changes and create value in the market to the community. The barrier of innovation in SMEs is financial difficulties due to high innovation costs and high economic risk, internal personal limitations in managing innovation process effectively and efficiently. Losing the market to find the needs of 
consumers and entering foreign markets, lengthy bureaucratic administrative procedures, regulations and laws to the contrary, the loss of intellectual property rights.

Ladislav, Mura \& Jan, Buleca (2012), the result is The most common forms of financing used by SMEs are short-term bank loans with maturities of less than one year, supplier credit and leases with a term of four to six years in the form of goods, machinery or cars. MSME management chooses more leasing because it is caused by the evaluation of stricter criteria on the bank.

Grisna, Anggadwita \& Qaanita Yuuha Mustafid (2014), the result is Only two independent variables that significantly influence the performance of SMEs variable enterpreuner aspects and aspects of HR competencies while the innovative aspects and sustainability (sustainability) does not affect the performance of SMEs.

Julien, Pollack \& Daniel Adler (2016), the finding is Project management skills, information technology professional skills and marketing skills will improve SMEs profitability.

Noruwa, AI and Emeka, J. E (2012), the research result is shown that microfinance banks have a very important role in reducing poverty through easy access to credit SME sector, but $\mathrm{t}$ ingkat high borrowing from the se c tor SMEs create serious problems for microfinance banks include documentation of the loan process, the wrong information, the identity of the applicant credit, lack of modern technology and the unstable economic situation in the country.

Neneh, NB (2012), the result is shown that The low level of entrepreneurial thinking in South Africa contributes to the failure of SMEs such as creativity, risk-taking, growth of mindset so that it is necessary to foster the success of SMEs in South Africa.

P. Eko, Prasetyo (2017), the research result is shown that "based on productivity analysis both with APC and Mundel methods, the productivity decreased except only in the Capital input variable which productivity level did not decrease. Based on the Mundel model, in more detail the decrease in productivity levels occurs in workers $>+1$ Foreman, sales worker, production worker, and manager worker. Furthermore, the new product development is also not effective yet, and the best strategy to be chosen in developing new products in new markets is diversification strategy. The implication of this research is that the TPT Industry in Central Java still has to continuously improve its productivity and improve the development of new products effectively using diversification strategy".

Ndou Valentina \& Sadguy Nezha (2011), the result $\mathrm{s}$ shown that Network technology new internet has provided equipment, applications and new opportunities for SMEs to organize and manage their activities in a new and more cost effective to build and maintain relationships with the outside world and to position them strategically to improve a dynamic environment for the success of the network requires a harmonization between the digital marketplaces business model and supply chain characteristics.

Tadjouddine (2011), the research result is E-Commerce technology can improve the competitiveness of SMEs because it is safe and accessible anywhere and anytime.

Supriyanto (2006), the result shown that The MSME sector has a large contribution to the employment of $99.45 \%$ and contribution to 
GDP by $30 \%$, but in its development is still experiencing various obstacles that is human resources, capital, market, management, technology and information.

Prasetyo, P, Eko (2008), the result is shown that the role of SMEs is the ability in employment so as to combat unemployment. The problems faced by UMKM are limited capital, low market share and competitiveness.

Shukriah A, \& Hamdani, I (2013), the result finding that with the enactment of MEA gives positive and negative impact to SMEs. The positive effect is that people can sell goods production to ASEAN countries with ease, while its negative impact is going to a lot of products coming into the country that resulted in competition becoming increasingly fierce so we need a strategy using comparative advantages namely by creating a distinctive and unique products and provide good service.

Based on the background of the problem, then the purpose of this study is to know the factors that can improve the competitiveness of SMEs, to find out how big these factors affect the increasing competitiveness of SMEs and to know the strategies that should be done by SMEs in facing ASEAN economics.

\section{RESEARCH METHODS}

The research method used is quantitative method. The unit of analysis in this study is the perpetrators of MSMEs using research variables: Strategy $(\mathrm{X})$, Competitiveness of SMEs (Y) and Economic Asean (Z). Data collection techniques are done by: Observation, the authors make observations to the location of research that is SMEs located in the district of Cirebon.

Interview, the authors do question and answer with officials at the Department of Industry and Commerce Cirebon industrial district that is Mr. Dhani and officers in the Office of Cooperatives and SMEs Cirebon Regency, namely Mr. Anton. Questionnaire, the authors make a list of questions to be filled by respondents about the circumstances experienced and perceived respondents associated with research variables. Library study, the authors collect references that have relevance to the topic of research.

Data type in this research use: 1 ) primary data that is interview with officer at Department of Industry and Trade of Regency of Cirebon and officer at Department of Cooperative and MSMEs of Regency of Cirebon and make questionnaires to be filled by respondents that is business actors of MSMEs. 2) secondary data that is data of number of MSMEs, center of MSMEs, funding of SMEs, coming from Industry and Trade Office of Cirebon regency.

Based on the information that the authors obtained from the industry and trade offices of Cirebon district through Cirebon district in the figure, that the number of MSMEs in Cirebon regency amounted to 10.795, so the population in this study amounted to 10.795 MSMEs. The sampling technique is simple random sampling method of sampling from a random member of the population (Riduwan \& Kuncoro, 2008: 41). To determine the sample size used Taro Yamane or Slovin formula, namely:

$\mathrm{n}=\mathrm{N} /\left(\mathrm{N} \cdot \mathrm{d}^{\wedge}{ }_{2+1}\right)$

Description :

$$
\begin{aligned}
\mathrm{n} \quad= & \text { number of samples } \\
\mathrm{N}= & \text { total population } \\
\mathrm{d} 2= & \text { precision (set at 10\% with 95\% } \\
& \text { confidence level) (Riduwan \& } \\
& \text { Kuncoro, 2008: 49) }
\end{aligned}
$$


Based on the calculation using slovin formula, then obtained the number of samples, namely:

$\mathrm{n}=10.795 /\left((10.795)(0.1)^{\wedge} 2+1\right)=99.08=100$

Thsen the sample used is 100 SMEs business actors. The analytical tool used is Path Analysis model of decomposition in order to test the effect of the nature of causality between the variables, both its direct and indirect, while the relationship that is nonkausalitas that occur between the exogenous variables not included in the calculation (Riduwan \& Kuncoro, 2008: 151). Decomposition research paradigm of causality between variables influence can be seen in Figure 1.

Table 1. Decomposition Effect of Interrelated Causality

\begin{tabular}{|c|c|c|c|}
\hline No & Type of Bussiness & Number of Employee & District \\
\hline 1 & Batik & 403 & $\begin{array}{ll}\text { Ciwaringin, } & \text { Plered, } \\
\text { Central Farmar } & \end{array}$ \\
\hline 2 & Natural Store & 344 & $\begin{array}{l}\text { Dukupuntang, } \\
\text { Palimanan, Depok }\end{array}$ \\
\hline 3 & Emping Melinjo & 132 & $\begin{array}{l}\text { Kedawung, Ciwaringin, } \\
\text { Gempol }\end{array}$ \\
\hline 4 & Convection & 595 & $\begin{array}{l}\text { Sumber, Arjawinangun, } \\
\text { Depok, Weru, } \\
\text { Pangenan, Plumbon, } \\
\text { Central Farmer }\end{array}$ \\
\hline 5 & Snacks & 417 & $\begin{array}{l}\text { Weru, Depok, Gempol, } \\
\text { Waled, Pangenan, } \\
\text { Plered, Middle Farmers }\end{array}$ \\
\hline 6 & Furniture & 1.220 & $\begin{array}{l}\text { Depok, Dukupuntang, } \\
\text { Weru, Plered, Central } \\
\text { Farmer }\end{array}$ \\
\hline 7 & Rattan & 1.305 & $\begin{array}{l}\text { Plered, Weru, Plumbon, } \\
\text { Central Tani, Depok }\end{array}$ \\
\hline 8 & Slipper & 20 & $\begin{array}{l}\text { Sumber, Plumbon, } \\
\text { Weru, Plered, Central } \\
\text { Farmer }\end{array}$ \\
\hline 9 & Fish Processing & 364 & $\begin{array}{l}\text { Mundu, Gebang, Waled, } \\
\text { Pangenan, Losari }\end{array}$ \\
\hline 10 & Woven Bamboo & 37 & $\begin{array}{l}\text { Greged, Dukuhpuntang, } \\
\text { Beber, Depok }\end{array}$ \\
\hline 11 & Tile & 22 & Ciwaringin, Pangenan \\
\hline 12 & Salt & 1.328 & $\begin{array}{l}\text { Mundu, Astanajapura, } \\
\text { Pangenan, Gunung Jati, } \\
\text { Kapetakan, } \\
\text { Suranenggala }\end{array}$ \\
\hline 12 & Mango & 20 & $\begin{array}{l}\text { Sedong, Astanajapura, } \\
\text { Greged, Lemahabang, } \\
\text { Beber, Susukan Lebak, } \\
\text { Dukupuntang, } \\
\text { Kedawung }\end{array}$ \\
\hline 14 & Red Onion & 9 & $\begin{array}{l}\text { Pabedilan, } \\
\text { Astanajapura, Pabuaran, } \\
\text { Babakan, Walet }\end{array}$ \\
\hline
\end{tabular}

Source : Department of Cooperative and UKM, Cirebon Distric 
Table 2 . Variable Operationalization

\begin{tabular}{|c|c|c|c|c|}
\hline Variables & Dimensions & Indicator & Scale & No Quesioner \\
\hline $\begin{array}{l}\text { Funding (DN) } \\
\left(\mathrm{X}_{1}\right)\end{array}$ & $\begin{array}{l}\text { Number of Ceiling, } \\
\text { Administrative } \\
\text { requirements, time } \\
\text { period }\end{array}$ & $\begin{array}{l}\text { The amount of guarantee } \\
\text { value, type of business } \\
\text { undertaken, submit a copy of } \\
\text { business documents, funding } \\
\text { framework, capital assistance }\end{array}$ & Ordinal & $1-10$ \\
\hline $\begin{array}{l}\text { Entrepreneurship } \\
\text { training }(\mathrm{PK}) \\
\left(\mathrm{X}_{2)}\right.\end{array}$ & $\begin{array}{l}\text { frequency Training, } \\
\text { Training materials, } \\
\text { Participants } \\
\text { Training, } \\
\text { innovation, } \\
\text { workforce } \\
\text { absorption, } \\
\text { productivity }\end{array}$ & $\begin{array}{l}\text { Time span, resource persons, } \\
\text { Innovation continue in change, } \\
\text { dynamic innovation } \\
\text { influencing to increase } \\
\text { consumption } \\
\text { innovation in creating new } \\
\text { product }\end{array}$ & Ordinal & $11-20$ \\
\hline $\begin{array}{l}\text { Business } \\
\text { Assistance (PU) } \\
\left(\mathrm{X}_{3}\right)\end{array}$ & $\begin{array}{l}\text { Internships, business } \\
\text { prospects, } \\
\text { information }\end{array}$ & $\begin{array}{l}\text { Duration of internship, } \\
\text { internship location, business } \\
\text { consultation, socializing } \\
\text { business prospects according } \\
\text { to type of business, access to } \\
\text { economic information }\end{array}$ & Ordinal & $21-30$ \\
\hline $\begin{array}{l}\text { Partnership (KM) } \\
\left(\begin{array}{ll}\mathrm{X} & 4\end{array}\right) \text { (Supriyadi, } \\
1997)\end{array}$ & $\begin{array}{l}\text { Joint marketing and } \\
\text { storage products, } \\
\text { business } \\
\text { development, } \\
\text { human resources } \\
\text { quality } \\
\text { Improvement, } \\
\text { Improvement of } \\
\text { business scale, } \\
\text { technology }\end{array}$ & $\begin{array}{l}\text { Improve product quality and } \\
\text { quantity, expand marketing } \\
\text { network, maximize profits, } \\
\text { improve human resources } \\
\text { quality, control product } \\
\text { quality, business development, } \\
\text { scale improvement, }\end{array}$ & Ordinal & $31-40$ \\
\hline $\begin{array}{l}\text { MSMEs } \\
\text { Competitiveness } \\
\text { (DN) } \\
\text { (Y) }\end{array}$ & $\begin{array}{l}\text { Revenue, } \\
\text { employment, use of } \\
\text { local raw materials, } \\
\text { business network }\end{array}$ & $\begin{array}{l}\text { Increased business revenues, } \\
\text { employment absorption, } \\
\text { utilization of local raw } \\
\text { materials, expanding business } \\
\text { networks }\end{array}$ & Ordinal & $41-50$ \\
\hline $\begin{array}{l}\text { ASEAN Economy } \\
(\mathrm{EA}) \\
(\mathrm{Z})\end{array}$ & $\begin{array}{l}\text { Can } r \text { compete, } \\
\text { dynamic, skilled } \\
\text { workforce, provide } \\
\text { facilities for business } \\
\text { movement }\end{array}$ & $\begin{array}{l}\text { Free trade, investment, services } \\
\text { and free capital flows, skilled } \\
\text { labor, e-ASEAN electronic } \\
\text { transactions, promoting } \\
\text { regional resources, increased } \\
\text { private sector roles, increased } \\
\text { infrastructure }\end{array}$ & Ordinal & $51-60$ \\
\hline
\end{tabular}




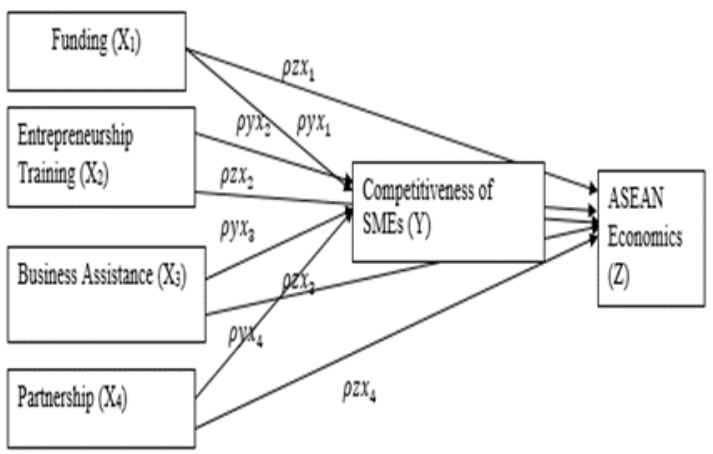

Figure 1. Decomposition Effect of Interrelated Causality

Source : Data Processed

The test path analysis decomposition model are as follows: Create a research paradigm, Formulate the research problem, Model hypotheses, Create path diagrams and structural equations, Examine each hypothesis for each Sub-Structure (Riduwan \& Kuncoro, 2008: 154-157) Operationalization of variables in this study can be seen in table 2 .

The research hypothesis based on the above problem formulation is as follows:

Ho: $\rho z y=\rho y x \_1=\rho y x \_2=\rho y x \_3=\rho y x \_4=0$,

Meaning there is no influence between variables $\mathrm{X}, \mathrm{Y}$ and $\mathrm{Z}$

Ha: $\rho z y=\rho y x \_1=\rho y x \_2=\rho y x \_3=\rho y x \_4 \neq 0$,

Meaning there is influence between variable $\mathrm{X}$ to $\mathrm{Y}$ and $\mathrm{Z}$

\section{RESULTS AND DISCUSSION}

Test Validity and Rentability Questionnaire, in conducting research, research instruments used must be tested the validity and reliability for the results of research can be accounted for.

Table 3. Summary of Path Coefficients, Direct Influence and Influence of Total Variable Funding, Entrepreneurship Training, Business Assistance and Competitiveness to ASEAN Economy

\begin{tabular}{llll}
\hline Influence of Variables & Directly & Indirect & Total \\
& & $\begin{array}{l}\text { Through } \\
\text { Competitiveness }\end{array}$ & 0.126 \\
\hline Funding to Competitiveness & & - & 0.278 \\
Funding to ASEAN Economy & 1.26 & 0.068 & 0.042 \\
Entrepreneurship Training on Competitiveness & 0.210 & - & 0.023 \\
Entrepreneurship Training on ASEAN Economy & 0.042 & 0.023 \\
Business Assistance to Competitiveness & 0,000 & - & 0.226 \\
Business Assistance to ASEAN Economy & 0.416 & 0.226 & 0.718 \\
Partnership on Competitiveness & 0,000 & - & 0.198 \\
Partnership Against ASEAN Economy & 0.718 & -0.192 & 0.543 \\
Competitiveness to ASEAN Economy & 0.389 & - & 0.543 \\
\hline Source : Data PrOCessed
\end{tabular}

Source : Data Processed

Instruments are declared valid if able to measure that must be measured, while the instrument is considered reliable if it produces a consistent measure even if used repeatedly. Based on the data in appendix the 
value of Alpha Crocbach is 0.821 greater than the required value of 0.6 so that the value of the instrument is reliable.

To determine whether all of these questions val id, then show Table 2 in the column Corrected item-total correlation, then compare the value of $r$ table with the value of $r$ count. If the value of $r$ count is greater than the value of $r$ table then the question is declared valid.

$\mathrm{R}$ value table (98: 0,05$)$ was 0.196 , and when compared with the value of $r$ count on the column Corrected item-total correlation, its value is greater than the value of $r$ table, so that the instrument is declared invalid.

Path Analysis Results from the results of data processing using SPSS AMOS version 22 produced the path diagram as shown in Figure 2.

The results showed that funding had a positive direct and significant influence on the competitiveness of $1.26=12.6 \%$ and funding influenced the ASEAN economy by $0.210=21 \%$, while through the competitiveness of $0.068=6.8 \%$.
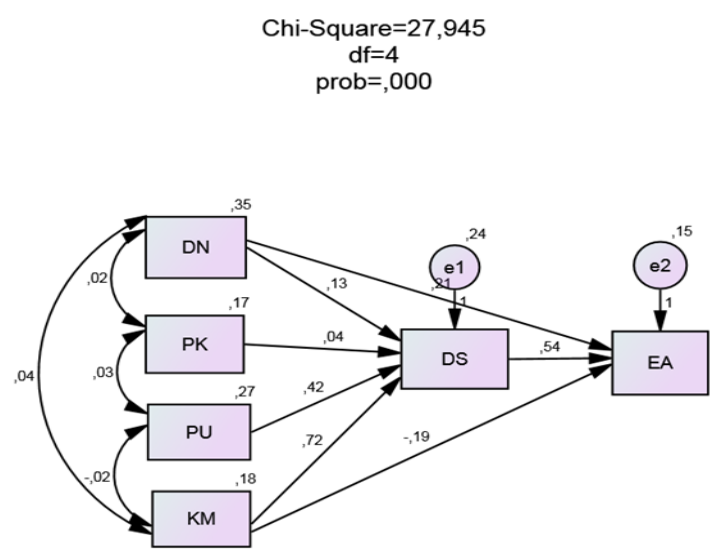

Figure 2. Diagram Line Data Processing

Results

Source : Data Processed

The results showed that funding had a positive direct and significant influence on the competitiveness of $1.26=12.6 \%$ and funding influenced the ASEAN economy by $0.210=21 \%$, while through the competitiveness of $0.068=$ $6.8 \%$. The positive direction means that if thefunding variable is increased.

Entrepreneurship training influences the competitiveness of $0.042=4.2 \%$ and entrepreneurship training affects the ASEAN economy by 0.000 , while through the competitiveness of $0.023=2.3$ means that entrepreneurship training does not directly affect the ASEAN economy.

Entrepreneurship training can increase the power competitiveness in facing the ASEAN economy. Business assistance has a direct. Influence on competitiveness of $0.416=41.6 \%$ and business assistance directly affects the ASEAN economy by o.ooo, while through the science of $0.226=22.6 \%$ means $t$

That business assistance does not directly affect the ASEAN economy but business. Assistance can increase the competitiveness of $22.6 \%$ in the face of the ASEAN economy. Partnership affects the competitiveness of 0.718 $=71.8 \%$ and partnerships directly affect the ASEAN economy by $0.389=38.9 \%$, while through the competitiveness of $-0.192=-19.2 \%$ Means partnership will reduce the level of competition with ASEAN countries others. Thus, the hypothesis that the authors propose accepted or Ho rejected. Competitiveness directly has a positive and significant effect on the ASEAN economy of $0.543=54 \cdot 3 \%$.

Table 4. capital of Assistance Shame

\begin{tabular}{lll}
\hline No & Name of Capital Assistance Scheme \\
\hline $\mathbf{1}$ & Credit Assistance Program (APBD) \\
$\mathbf{2}$ & $\begin{array}{l}\text { People's Business Credit (KUR) } \\
3\end{array}$ & $\begin{array}{l}\text { Revolving Fund Management } \\
\text { (LPDB) }\end{array}$ \\
& Institute \\
4 & Credit of People's Love (KCR) \\
5 & Social Aid (Bansos)
\end{tabular}

(Source: Dinas Koperasi and UMKM Cirebon district, 2017) 
Among all the above variables, variables that influence on sa ing power is variable partnerships Based on the information that the authors obtained from the tenderloin il In the field of cooperatives and SMEs capital for central and local governments provide a wide range of capital aid schemes, among others: interview with petuga s in the Department of Cooperatives and SMEs that the funding offered by the government are pretty much like KCR (Credit Cinta Rakyat), KUR (Kredit Usaha Rakyat), cooperatives and others just to be it is questionable whether such funding has been right on target or not so necessary monitoring and evaluation, as it is based on information from SMEs in other villages adjacent to the village to get funding to SMEs, but SMEs in the village do not get funding. Entrepreneurship training is a government program that is often held recently in Cirebon regency, but there are still community of UMKM perpetrators who claimed not to know the information of entrepreneurship training program so that there needs to be comprehensive socialization to every village in Cirebon regency. Business mentoring done by the Department of Cooperatives and SMEs and the Department of Industry and Trade in Cirebon by creating centers of SMEs which consists of a minimum of ten SMEs which have the same effort to facilitate dal am mentoring effort, but the business assistance is limited on business that has characteristic for Cirebon regency, such as furniture, sandals, rattan, salt, natural stone, snacks, emping melinjo, batik trusmi, batik ciwaringin and others, while for other small and scattered UMKM business activity sentragrouped into centers of industrial enterprises or SMEs. Partnerships undertaken by UMKM business actors have reached inter-provinces and some even up to the ASEAN scale such as rattan, but partnerships conducted more in the field of marketing.

\section{CONCLUSION}

Based on the results of this study concluded that the variable funding, entrepreneurship training, business mentoring and partnership a positive and significant impact on the competitiveness $d$ aya, meaning that if these variables improved, it will increase the competitiveness of SMEs in the face of the ASEAN economy. Of all the independent variables that most influence terha dap partnership and competitiveness are the most influential on the ASEAN economic competitiveness is variable. Therefore, if SMEs want to survive in the ASEAN economic market should increase competitiveness, and to enhance competitiveness, SMEs are required to establish partnerships with various parties that there is relevance to the SME business. By establishing partnerships there will be many advantages obtained by UMKM business actors such as technology transfer, product quality improvement, employee quality improvement, funding, raw material supply, marketing both traditional and internet based, product design, business assistance and many more benefits. will be obtained by the perpetrators of MSMEs.

\section{REFERENCES}

. The Central Bureau of Statistics, in 2015, Number of Small Micro Industrial Company, accessed via www.bps.go.id on May 15, 2015

Blocher, 2000, the Cost Management, Translation Susty Ambarriani, Salemba Four, Jakarta

Department of Cooperatives, 2015, the Working Group of the Ministry of Cooperatives and SMEs MEA, accessed via www.depkop.go.id on May 12, 2015 
Efendi Arianto, 2015, the definition of National Competitiveness / State, accessed through http://strategika.com/2008/o8/19/daya-saing on May 15, 2016

Ernayanti, Tri, 2015, Application of SWOT Analysis In Competitiveness Improvement Strategies For Dealing Muslim traders AEC, Thesis, Negeri Walisongo Islamic University, Semarang

Grisna, Anggadwita \& Qaanita Yuuha Mustafid, 2014, Identification of Factors Influencing the Performance of Small Medium Enterprises (SMEs), Procedia Social and Behavioral Sciences, 115, (415-423)

Gusmardi Bustami, 2015, Towards the ASEAN Economic Community, the Ministry of Trade of Indonesia, Jakarta

Hamdy, Hadi, 2001, the International Economy - Theory and Policy, International Trade, Book 1, Ghalia Indonesia, Jakarta

Presidential Instruction No. RI. 6 Year 2014 on Improving National Competitiveness in Order to Facing the ASEAN Economic Community

Julien, Pollack and Daniel Adler, 2016, the Skills That Improve Profitability: The Relationship Between Project Management, IT Skills, and Small to Medium Enterprise Profitability, International Journal of Project Management, 34, 831-838

Presidential Decree No. RI. 37 of 2014 About the National Committee for the Preparation of the Implementation of the Economic Society Association of Southeast Asian Nations

Ladislav, Mura \& Jan, Buleca, 2012, Evaluation of Financing Possibilities of Small and Medium Industrial Enterprises, Procedia Economics and Finance, 3, 217-222

Ndou, V \& Sadguy, N, 2011, Digital Marketplaces as a viable model For SME Networking, IGI Global, Italy

Neneh, NB, 2012, An Exploratory Study on the Entrepreneurial Mindset in the Small and Medium Enterprise (SME) Sector: A South African Perspective on fostering the Small and Medium Enterprise (SME) Success, African Journal of Business Management. 6 (9): 33643372

Noruwa, AI \& Emeka, EJ, 2012, The Role and Sustainability of Microfinance Banks in Reducing Poverty and Development of Entrepreneurship in Urban and Rural Areas in
Nigeria, the International Journal of Business Administration. 3 (3): 33-40

P, Eko, Prasetyo, 2008, The Role of Micro, Small and Medium Enterprises in Poverty Reduction Policies and Unemployment, AKMENIKA UPY, (2): 1-13

P, Eko, Prasetyo, 2017, Productivity of Textile Industry and Textile Products in Central Java, Journal of Economics and Policy (JEJAK), 10 (2), 257-272

Rangkuti, Freddy 2006, Analsisis SWOT technique Dissecting the Business Case, Gramedia Pustaka Utama, Jakarta

Riduwan \& Kuncoro. A. Engkos 2008, How to Use and Interpret the Path Analysis (Path Analysis), Alfabeta, Bandung

Rival, Veitzhal 2006, Credit Management Hand Book: Theories, Concepts, Procedures and Applications, Student Practical Guide, Bankers and Customers, King Grafindo Persada, Jakarta

Rudianto 2009, Budgeting, Erland, Jakarta

Sudaryanto, Ragimun \& Wijayanti, R, R, 2015, the SME Empowerment Strategy Facing ASEAN Free Market, State University of Jember, Jember

Supriyanto 2006, Empowerment, Micro, Small and Medium Enterprises (SMEs) As One Of The Poverty Reduction Efforts, Journal of Economics and Education. 3 (1): 1-16

Syukriah, A \& Hamdani, I, 2013, the existence of SMEs Through Improved Comparative Advantage In Order Facing AEC 2015, in Temanggung, Economics Developments Analysis Journal, 2 (2): 110-119

Tadjouddine, M. E, 2011, E-Commerce Systems For Software Agents: Challenges and Opportunities, IGI Global, China

Tambunan, Tulus, 2001, the development of SMEs in Indonesia: Do They move by the Spirit of Entrepreneurship, USAKTI, Jakarta

Law of the Republic of Indonesia No. 17 of 2012 on Cooperatives

Act No. 20 of 2008 on small and medium micro enterprises

Zuraida, Hani, Zulkepli; Norlena, Hasnan \& Shahimi, Mochtar, 2015, Communication and Service Innovation in Small and Medium Enterprises (SMEs), Procedia-Social and Behavioral Sciences, 211, $437-441$ 


\section{APPENDIX}

Item Total Statistics

\begin{tabular}{|c|c|c|c|c|}
\hline & $\begin{array}{c}\text { Scale Mean if Item } \\
\text { Deleted }\end{array}$ & $\begin{array}{l}\text { Scale Variance if } \\
\text { Item Deleted }\end{array}$ & $\begin{array}{l}\text { Corrected Item- } \\
\text { Total Correlation }\end{array}$ & $\begin{array}{l}\text { Cronbach's Alpha } \\
\text { if Item Deleted }\end{array}$ \\
\hline$P_{1}$ & 180,36 & 392.435 &, 399 &, 814 \\
\hline $\mathrm{P}_{2}$ & 180.51 & 396,818 &, 504 &, 814 \\
\hline $\mathrm{P}_{3}$ & 180.42 & 403,074 &, 318 &, 817 \\
\hline $\mathrm{P}_{4}$ & 180.22 & 405,224 &, 273 &, 818 \\
\hline $\mathrm{P}_{5}$ & 180.41 & 413.436 &, 244 &, 822 \\
\hline P6 & 180.52 & 410,252 &, 294 &, 822 \\
\hline Q7 & 180.61 & 408,584 &, 228 &, 821 \\
\hline P8 & 180.55 & 393,301 & , 445 &, 814 \\
\hline P9 & 180.97 & 393,161 & , 415 &, 814 \\
\hline P10 & 182.14 & 407,031 &, 293 &, 819 \\
\hline P11 & 181.77 & 395,169 &, 421 &, 814 \\
\hline $\mathrm{P}_{12}$ & 182.17 & 431,132 &, 300 &, 832 \\
\hline$P_{13}$ & 180.24 & 413,639 &, 248 &, 822 \\
\hline $\mathrm{P}_{14}$ & 181.80 & 413,717 &, 235 &, 823 \\
\hline $\mathrm{P}_{15}$ & 180.47 & 410,494 &, 270 &, 820 \\
\hline P16 & 180.43 & 406,551 &, 280 &, 818 \\
\hline $\mathrm{P}_{17}$ & 180.70 & 405,444 &, 248 &, 818 \\
\hline $\mathrm{P} 18$ & 181.50 & 397,283 & , 298 &, 817 \\
\hline P19 & 181.26 & 394,396 &, 378 &, 815 \\
\hline $\mathrm{P}_{20}$ & 181.99 & 429,061 &, 319 &, 830 \\
\hline$P_{21}$ & 181.98 & 398,727 &, 332 &, 816 \\
\hline $\mathrm{P}_{22}$ & 181.43 & 401,561 &, 271 &, 821 \\
\hline $\mathrm{P}_{23}$ & 181.34 & 412,469 &, 261 &, 822 \\
\hline $\mathrm{P}_{24}$ & 181.39 & 394,281 &, 455 &, 814 \\
\hline $\mathrm{P}_{25}$ & 181.20 & 400,424 &, 318 &, 817 \\
\hline $\mathrm{P}_{2} 6$ & 182.16 & 404,540 &, 282 &, 820 \\
\hline$P_{27}$ & 181.26 & 409,548 &, 271 &, 824 \\
\hline $\mathrm{P} 28$ & 181.65 & 393,684 &, 371 &, 815 \\
\hline P29 & 181.79 & 407,258 &, 270 &, 820 \\
\hline$P_{30}$ & 180.61 & 422,887 &, 265 &, 828 \\
\hline$P_{31}$ & 181.18 & 411,119 &, 263 &, 823 \\
\hline$P_{32}$ & 179.90 & 415,141 &, 207 &, 823 \\
\hline$P_{33}$ & 180.14 & 417.213 &, 251 &, 824 \\
\hline$P_{34}$ & 180.72 & 404,628 &, 283 &, 818 \\
\hline$P_{35}$ & 181.27 & 407,613 &, 279 &, 820 \\
\hline $\mathrm{P}_{36}$ & 180.49 & 401,606 &, 243 &, 818 \\
\hline
\end{tabular}




\begin{tabular}{|c|c|c|c|c|}
\hline$P_{37}$ & 181.78 & 403,143 &, 383 &, 816 \\
\hline$P_{3} 8$ & 181.34 & 400,489 &, 326 &, 817 \\
\hline$P_{39}$ & 181.88 & 404,511 &, 206 &, 819 \\
\hline $\mathrm{P}_{40}$ & 181.42 & 418,428 &, 274 &, 827 \\
\hline $\mathrm{P}_{41}$ & 181.33 & 391,153 &, 445 &, 813 \\
\hline $\mathrm{P}_{42}$ & 180.53 & 392,959 &, 587 &, 812 \\
\hline$P_{43}$ & 181.55 & 411,866 &, 267 &, 822 \\
\hline $\mathrm{P}_{44}$ & 180.68 & 381,917 &, 664 &, 808 \\
\hline $\mathrm{P}_{45}$ & 180.91 & 409,032 &, 245 &, 820 \\
\hline $\mathrm{P}_{4} 6$ & 180.21 & 397,582 & , 376 &, 815 \\
\hline $\mathrm{P}_{47}$ & 181,83 & 396,789 &, 452 &, 814 \\
\hline $\mathrm{P}_{4} 8$ & 180.88 & 393,985 &, 482 &, 813 \\
\hline$P_{49}$ & 181,74 & 398.942 &, 363 &, 816 \\
\hline $\mathrm{P}_{50}$ & 180.95 & 388,189 &, 513 &, 812 \\
\hline$P_{51}$ & 180.79 & 389,077 & , 495 &, 812 \\
\hline$P_{52}$ & 181.02 & 392,545 &, 438 &, 814 \\
\hline$P_{53}$ & 180.91 & 406,547 &, 227 &, 819 \\
\hline$P_{54}$ & 180.98 & 409,050 &, 266 &, 820 \\
\hline$P_{55}$ & 180.55 & 408.210 &, 231 &, 819 \\
\hline $\mathrm{P}_{5} 6$ & 181.34 & 403,378 &, 214 &, 819 \\
\hline$P_{57}$ & 181,53 & 392.898 &, 420 &, 814 \\
\hline $\mathrm{P}_{5} 8$ & 182.53 & 409,039 &, 252 &, 820 \\
\hline$P_{59}$ & 181.59 & 393,658 &, 492 &, 813 \\
\hline P6o & 180.80 & 401,737 &, 297 &, 820 \\
\hline
\end{tabular}

Reliability Statistics

\begin{tabular}{cc}
\hline Cronbach's Alpha & N of Items \\
\hline 821 & 60 \\
\hline
\end{tabular}

Total Effect (Group Number 1- Default Model)

\begin{tabular}{cccccc}
\hline & $\mathrm{X}_{4}$ & $\mathrm{X}_{3}$ & $\mathrm{X} 2_{2}$ & $\mathrm{X}_{1}$ & $\mathrm{Y}$ \\
\hline $\mathrm{Y}$ &, 718 &, 416 &, 126 &, 000 &, 000 \\
$\mathrm{Z}$ &, 198 &, 226 &, 278 &, 533 &, 543 \\
\hline
\end{tabular}

Standardized Total Effect (Group Number 1- Default Model)

\begin{tabular}{cccccc}
\hline & $\mathrm{X}_{4}$ & $\mathrm{X}_{3}$ & $\mathrm{X}_{2}$ & $\mathrm{X}_{1}$ & $\mathrm{Y}$ \\
\hline $\mathrm{Y}$ &, 488 &, 351 &, 028 &, 000 &, 000 \\
$\mathrm{Z}$ &, 159 &, 226 &, 018 &, 643 &, 643 \\
\hline
\end{tabular}


Direct Effects (Group Number 1- Defaults Model)

\begin{tabular}{cccccc}
\hline & $\mathrm{X}_{4}$ & $\mathrm{X}_{3}$ & $\mathrm{X} 2_{2}$ & $\mathrm{X}_{1}$ & $\mathrm{Y}$ \\
\hline $\mathrm{Y}$ &, 718 &, 416 &, 042 &, 000 &, 000 \\
$\mathrm{Z}$ &, 192 & ,000 & ,000 &, 533 &, 543 \\
\hline
\end{tabular}

Standarised Dirext effext (Group Number 1 - Default Model)

\begin{tabular}{cccccc}
\hline & $\mathrm{X}_{4}$ & $\mathrm{X}_{3}$ & $\mathrm{X}_{2}$ & $\mathrm{X}_{1}$ & $\mathrm{Y}$ \\
\hline $\mathrm{Y}$ &, 488 &, 351 &, 028 &, $\mathbf{2 0}$ & ,000 \\
$\mathrm{Z}$ &, 154 &, 000 & ,000 &, 237 &, 643
\end{tabular}

Indirect Effects (Group Number 1- Default Model)

\begin{tabular}{cccccc}
\hline & $\mathrm{X}_{4}$ & $\mathrm{X}_{3}$ & $\mathrm{X} 2_{2}$ & $\mathrm{X}_{1}$ & $\mathrm{Y}$ \\
\hline $\mathrm{Y}$ & ,000 & ,000 & ,000 & ,000 & ,000 \\
$\mathrm{Z}$ &, 389 & ,226 & ,023 & ,068 & ,000 \\
\hline
\end{tabular}

Standardized Inderect Effects (Group Number 1- Default Model)

\begin{tabular}{cccccc}
\hline & $\mathrm{X}_{4}$ & $\mathrm{X}_{3}$ & $\mathrm{X}_{2}$ & $\mathrm{X}_{1}$ & $\mathrm{Y}$ \\
\hline $\mathrm{Y}$ & ,000 & ,000 & ,000 & ,000 & ,000 \\
$\mathrm{Z}$ &, 314 &, 226 &, 018 &, 077 & ,000 \\
\hline
\end{tabular}

